\title{
Susan's Disempowering Portrayal in The Chronicles of Narnia: Prince Caspian and its Source Text
}

\author{
$1^{\text {st }}$ Eddline Kusuma Andani \\ English Studies Program, Faculty of \\ Humanities \\ Universitas Indonesia \\ Depok, Indonesia \\ eddlinekusuma2@gmail.com
}

\author{
$2^{\text {nd }}$ Dhita Hapsarani* \\ Literature Department, Faculty of \\ Humanities \\ Universitas Indonesia \\ Depok, Indonesia \\ dhitahapsarani@gmail.com
}

\begin{abstract}
Films are often motivated to correct social anomalies, and some recent movies have sought to empower women through the depiction of strong, foregrounded female characters whose voices and actions would otherwise fade into the background. The Chronicles of Narnia: Prince Caspian (2008) [1] is a film adaptation of a 1951 children's novel. The film delivers the plot differently from its source and institutes substantial changes. Particularly, Susan Pevensie's character is portrayed in a more empowering manner in the film. Using the qualitative method, this study aims to demonstrate that while Susan's character is more empowered in the film than in the original novel, her treatment in the film does not achieve gender equity. This study utilizes Trites's [2] agency theory, Hall's [3] representation theory, and Bordwell and Thompson's [4] elements of film analysis to identify the differences in the actualization of Susan and the male characters and to comparatively analyze her agency, voice, and power in the source novel and the studied film. The results of the investigation reveal that Susan's standing in the film is not very different from her positioning in the novel as inferior to the male characters. Some mise-en-scènes still represent the patriarchal system in gender-stereotyped portrayals that are counterproductive to the film's effort to empower Susan.
\end{abstract}

Keywords-Narnia, Prince Caspian, Susan, agency, empowerment, film analysis

\section{Introduction}

Recent TV and film adaptations of the fairy tales and fantasy stories of a bygone era have introduced notable changes in the portrayal of female protagonists. McDonough [5] observes that twenty-first-century audiences usually call for stronger heroines, especially in the genres of fantasy and dystopian fiction. Disney fairy tale films, for instance, have changed substantially in response to the changing perception of gender roles and the twenty-first-century quest to erase gender-based stereotypes.

Girls in children's books often appear to enjoy more freedoms "than the real girls who were their actual counterparts in British and North American cultures" [2]. The plot and characterization of the film The Chronicles of Narnia: Prince Caspian (2008) [1], differed drastically from its source material, Prince Caspian: The Return to Narnia (1951). The plot of the film adaptation includes more battle scenes involving female characters. The characters are also depicted slightly differently in the film adaptation. The starkest divergence may be observed in the portrayal of Susan Pevensie, who whines less, takes an active part in battles, and becomes romantically involved.
Several studies have attended to the portrayal of the female characters in The Chronicles of Narnia series, reading their representation in different ways. Many of the extant investigations have focused specifically on Susan Pevensie. These studies demonstrate that the novels infuse certain stereotypical features into Susan's character, painting her as a dependent and vain female teenager with traits that are regarded as feminine. Duine [6] argues that Susan's gift from Father Christmas in the second novel, The Chronicles of Narnia: The Lion, The Witch, and The Wardrobe (1950) proves that as a female character, Susan is expected to be a damsel in distress: she lacks the ability to solve her own problems and is illustrated as relying on the help of others. Her Christmas present is thus an "emergency" horn that can be used to call for help. Pullman [7] elucidates Susan is excluded from going to heaven in the last novel simply because her interests are more vested in the superficial and worldly desires of women: "nylons, lipsticks, and invitations" (para.11).

However, some critics have argued otherwise. Schilling [8] contends that despite pronouncements regarding Lewis' misogyny toward the female characters of the Narnia series, their portrayals do not offer more or less "strengths and weaknesses than the males" (p. 3). Several studies attending to the film adaptation of the 1951 novel disagree with the last observation. O'Donnell [9], for instance, reveals the underlying aspects of the film that indirectly demonstrate and emphasize power structures that contribute to the sexism observable in Susan's portrayal: her romantic involvement with Caspian in the film adaptation [1] is cited as one example. The director of the film, Andrew Adamson, claims that he intended the female personalities of the film to be unlike their characterization in the novels and that he made them as empowered as their male counterparts [10]. Nickel [11] agrees and claims that the differences between the Narnia novels and the film echo the distinctions between "Lewis' conservative beliefs and the liberal atmosphere of Hollywood after the second-wave of the feminist movement" (p. 270). However, a deeper analysis divulges that Susan's character in the film is not as empowered as it is claimed to be. Susan's personal traits and her environment are still borrowed from the novel, and they accord her a status that is inferior in comparison to the male characters.

The extant research on this theme has not discussed the issue of Susan's agency as represented by the way she voices her opinions, her decision-making, and the ambiguities in her depiction in the film. This paper centers on Susan's 
representation in the film adaptation vis-à-vis her portrayal in the novel. By examining Susan's voice and decision-making abilities, the present study aims to reveal the film's stance toward women in power. It proves that the liberties accorded to Susan's in the film The Chronicles of Narnia: Prince Caspian [1] are still overshadowed by the ways in which the male characters perceive her competency, and how her agency is depicted.

\section{Method}

This study uses the qualitative approach of library-based research. The corpus of this study comprises the novel Prince Caspian: The Return to Narnia (1951) and its film adaptation, The Chronicles of Narnia: Prince Caspian (2008). The two versions of the narrative are compared to identify the differences and similarities in the rendering of Susan's character and in the depiction of her agency as a female member of the group. This study further analyzes the film's cinematographic techniques and closely scrutinizes certain scenes to reveal how Susan is represented, positioned, and empowered. To this end, this study refers to Stuart Hall's [3] representation theory, Trites's [2] conception of agency, and David Bordwell and Kristin Thompson's treatise, Film art: An introduction (10th edition) [4].

Hall's [3] theory of representation aids the examination of how Susan Pevensie is represented as a female character in the film. It affords a special focus on certain scenes that display how the phenomena that surround Susan reveal gender values the film attempts to convey. Trites's [2] concept of agency helps to analyze whether and how Susan's opinions control her actions and to probe whether and how Susan is an active and subjective agent in the film. Finally, David Bordwell and Kristin Thompson's seminal work, Film art: An introduction (10th edition) [4] is employed to uncover messages delivered by some of the film's scenes.

Thus, representation theory, the concept of agency, and elements of film analysis are employed in this study to evaluate the ways in which Susan is portrayed in both the novel and its film adaptation. Further, the present study assesses Susan's female agency and attempts to ascertain the time-based differences in her rendering. Does Susan's representation in the $21^{\text {st }}$-century film adaptation differ adequately from the $20^{\text {th }}$-century novel to appropriately underscore the transformations in societal attitudes and values in the time that has passed in between her two depictions?

\section{Results and Discussion}

\section{A. The Chronicles of Narnia: Prince Caspian (2008): Susan Pevensie's Empowering Portrayal}

Agency is an integral part of the manner in which Susan is portrayed in both the novel and the film. Between them, the original text explores her female agency to a lesser extent in comparison to the later film version. Weitzman, Eifler, Hokada, and Ross [12] reviewed children's books that won the Caldecott Medal and were published between the late 1930s and the early 1970s. They found serious underrepresentation of female characters in titles, central roles, and illustrations in the picture books of that time. The term "separate spheres" was commonly used in Britain from the $1870 \mathrm{~s}$ to differentiate the spaces men and women occupied in society. However, the term is deemed to be an “inadequate characterization of women's (and men's) roles in the nineteenth- and twentieth-century British society" 13]. Prince Caspian: The Return to Narnia [14] was published in 1951, and it is unsurprising that Susan's portrayal corresponds to the gender values of that era. In the novel, she holds the title of High Queen, which enables her to become involved in decision-making and to voice her opinions like her older brother, Peter, who is High King. Despite this position of power and the potential that it bestows on her, Susan generally plays an insignificant role in the kingdom's decision-making process. Her title and position in Narnia become colored by the prevailing hierarchical social attitudes that naturally entrust higher levels of authority to men. It is not that the women are completely silenced, but that there are limits imposed on their voices and actions to maintain the prevailing hegemony.

The film adaptation The Chronicles of Narnia: Prince Caspian (2008) [1], however, seems to uplift Susan's role from that of a passive participant to an active agent. She is given more strength, space, and significant tasks to fulfill. For instance, the film provides a stronger representation of her prowess in archery, using the zoom-in technique that shows a more centralized shot of Susan's face. This close-up reveals that unlike the novel's description of a similar scene, Susan is unafraid and does not become pale when confronted with battle.

The comparable scene in the novel describes Susan shooting arrows at a boat owned by two Telmarine soldiers who are trying to drown Trumpkin in the river:

... and all at once the soldier threw up his arms, dropping the Dwarf into the bottom of the boat, and fell over into the water. He floundered away to the far bank and Peter knew that Susan's arrow had struck on his helmet. He turned and saw that she was very pale but was already fitting a second arrow to the string (Lewis, 2015 p. 36) [14].

Despite Susan's mastery in archery, she lacks agency in the novel. It is safe to say that the gender values of the Victorian Era that Lewis "desired to hold on to" [15] restricted women from being granted a more active agency. Vermeij [15] stated that "Victorian Britain was a gender divided culture, separating boys and girls and their literature." Books intended for boys were themed on action, adventure, and heroics; those intended for girls were centered on domestic matters (Townsend, 2003) [16], [15]. The novel seems to deliver the message of the era's propaganda that "emphasized that women's work within the home equated to a contribution to fighting the war." However, the film affords Susan a space outside the domestic sphere and shows her strength and determination in battle (Ward [13]).

The passage quoted above from the book also reveals that Susan is fast and precise in battle. Cruea [17] states that a nineteenth-century woman was considered to be "a pillar of moral strength and virtue." Yet, Victorian women were generally depicted as "delicate and weak" (p. 189). They were associated with the likelihood of fainting or falling ill and painted as emotionally weak. Further, they were denied physical activity because of their physical fragility. In the novel, Peter regards Susan as a girl who encompasses these feminine traits when he notices her paleness as she shoots her arrow. Susan's unnatural pallor proves that women 
should sustain their feminine morality, and are not suited to violence because of their emotional and physically not up to the task. These values contradict Susan's actual abilities: she is fast, precise, and agile in shooting her target.

Susan's skills combat are also questioned in the novel when she does not shoot the wild bear that is about to attack her little sister. It is difficult for her to decide whether the bear is a Narnian who intends no harm or a wild animal that intends to injure. According to Cruea [17], a "'True Woman" was designated as the symbolic keeper of morality and decency within the home, being regarded as innately superior to men when it came to virtue" (p. 189). Thus, women are often shown as unable to act to harm others because they must know what is right and wrong and to maintain their virtuous essence. Susan's action is delayed by this decisionmaking process.

In contrast, the film shows that Susan is brave in situations that require her to fight alongside the male characters. A gender-neutral equivalence of strength and skill is thus preferred by the film. However, like the novel, the film also portrays her as reluctant to speak up, and therefore, there is a contradiction in the film's positioning of Susan as a strong female character who is equal to her male companions in every way. On one occasion in the movie, Susan does not say anything even though she knows that Peter has chosen the wrong way to Aslan's How to meet Caspian. She keeps her opinion to herself up until later when they have already journeyed far into the woods. Peter chides her for not bringing it up earlier. Instead of believing that her opinion might matter, she responds with words that seem akin to whining: "I knew all along we'd get lost in these woods." (p. 109[13]). Tsatsa [18] illuminates John Stephens' schema for masculinity and femininity in which the feminine traits included being "dependent" and "powerless." Citing Stephens, Tsatsa [18] further states that females were expected to conform to these prescribed stereotypes; otherwise they would become undesirable. Susan keeps conforming to these female stereotypes and to prove herself to be powerless and dependent

The novel portrays Susan as a female who is not used to voicing her opinions, even when they carry critical import. First, she refrains from speaking up. Second, she relies on Peter to lead the way. When Peter chooses the wrong way, she chooses to be silent instead of informing him about her ideas and only tells him later. Her inability to remind Peter does not benefit others. Susan's hesitation may be attributable to her not being used to being involved in important decision-making, especially in matters relating to warfare. In the novel, it is always the men who are engaged in decision-making regarding battle strategies. Susan is never involved. Thus, Susan does not immediately tell Peter that she thinks they are taking the wrong way. Conditioned by patriarchy, she has internalized the idea that her voice does not matter. However, there is an ambivalence in her silence about taking the wrong way and Peter chides her about it. Susan's dilemma is understandable. On the one hand, a woman's voice is not considered important in matters pertaining to battle. On the other hand, she is blamed because she did not voice her opinions when the men take the wrong way. Moreover, in the novel Susan is never involved in the battles. She is always positioned on the sidelines, away from the risks of combat.
To sum up, Susan's lack of agency may be influenced by the author's own social conditioning that results in Susan's portrayal as a stereotypically feminine character. While some aspects of this stereotype are retained in the film, the 2008 version of Susan is relatively more empowered. These subtle yet important deviations in Susan's portrayal from the novel evidence that some efforts were made by the filmmakers to eliminate the unfair and gendered depiction of this character. The analysis of some of the film's shots demonstrates that Susan's portrayal is more equal in its footing to the male characters.

\section{B. Susan Pevensie: The Traditional Stereotypes of Women as Heroines}

Strength is not Susan's principal trait in the novel. The film makes her stronger as is evidenced by her decision to engage in battle. This decision is her own: no one tells her to join the army. She is strong and passionate in the battlefield. Nevertheless, despite the more empowered portrayal, the film still reflects certain conventional attitudes to femininity.

Susan's character in the film embodies the conventional characteristics ascribed to women in Hollywood films. According to Dutt [19], women can be "independent, powerful, and agentive" but a lot still submit to "patriarchal constructions" (p. 2). Susan's subordination to Peter stems from his higher social position; even though she is free to refute Peter's arguments or orders, Susan does not. Some of the scenes that show her lack of agency are related to the notion of authority, which she seems to lack or not put on display. Clark and Henderson [20] are cited in Barker (2003) [20] to claim that "cculturally generated agency' arises from a differing distribution of social resources, which means that certain people in specific situations will possess a greater ability to act, or access more agency, because of cultural and social structures." For example, Susan's brother Peter can act and speak his mind with more ease.

Peter is also dismissive of Susan's warning to stop the attack on Miraz's castle and to notify the Narnians waiting outside the castle to retreat $(01: 14: 19-01: 14: 32[1])$. Nickel [10] argues that Susan's inclination toward practicality causes her to engage in a power struggle with the male characters. The author further argues that the filmmakers wanted to make Susan the voice of reason (as in this scene) which stands out in the clamor of men's egotistical actions. Susan is provided a space to speak up in this instance, and she does. However, Peter still insists on acting on his decisions, and Susan is compelled to follow him. Karolina from Marvel's Runaways [20] often offers novel suggestions for her group, but these ideas are not influential enough to alter the main plot. According to Nickel [10], this lack of effect proves that Karolina exercises less power in the group, which deprives her of the opportunity to gain more agency by excluding her from important decisions and actions. It can be said that "her agency is limited socially" [20]. In Susan's case, her suggestion is either not heard or is not considered important enough to the decision-making process because Peter obstructs the consideration of Susan's suggestion. Thus, she is denied the opportunity to attain more agency. Peter refutes and underestimates Susan's advice and doubts her capacity to be right. Perhaps he tries to reassert his power as king by silencing Susan's voice. If Susan does not object further to Peter, it is because between the siblings as for the 
other characters, Peter is believed to embody the highest authority.

Susan is also painted as weak and dependent. O'Donnell [9] contends that the film sexualizes her. Unlike the novel, the film's Susan does not turn away from desire. The author further argues that this characterization places Susan in the "weaker role" that allows "the more capable Caspian to save her" (p. 45). Besides having to be saved by Caspian, she must be protected by Trumpkin, another male figure, in another scene. Thus, Susan is twice saved in the film by males: first when Susan and Lucy have to go to find Aslan, and second when Caspian offers the horn back to Susan but she refuses to accept it, saying that Caspian might need it, "You might need to hold on to it. You might need to call me again" (01:38:36[1]). This horn was left in Narnia in the absence of Susan and her siblings from the kingdom. In the film, this horn is in Caspian's possession. Caspian uses it at the beginning of the film to call for help, which finally arrives in the form of the Pevensie siblings returning to Narnia after a long absence.

After the scene where Susan refuses to take the horn, she is rescued by Caspian as she is defending herself. Despite her apparent empowerment, Susan must still be saved by a man when she is fighting for herself. Bordwell and Thompson [4] state that the functions of slow-motion are often utilized to convey the impression "that the action takes place in a dream or fantasy." Slow-motion is also used to deliver the idea of immense power. It could be employed to emphasize, "becoming a way of dwelling on a moment of spectacle or high drama" (p. 168). In this scene, Susan's engagement in combat is shot in slow-motion (01:42:06 - 01:42:38[1]), emphasizing her skill in archery and her ability to fight alone against several Telmarine soldiers. She manages to shoot four Telmarine soldiers but is eventually defeated. She falls to the ground and Caspian rescues her. Caspian manages to steal Susan's spotlight by killing a Telmarine soldier with a single slash of his sword. Therefore, Caspian's act of saving Susan devalues her empowered portrayal in the same scene.

After the fight described above, Caspian asks Susan as he pulls her off the ground, 'You're sure you don't need that horn?" (01:43:16[1]). The purpose of the horn is to call for help in any form. Earlier, Susan has left the horn with Caspian in case he requires help. In Hall's words [3], "To represent also means to symbolize, stand for, to be a specimen of, or to substitute for; ...” (p. 16). Susan's horn represents dependence. Letting go of the horn may symbolize that Susan has finally let go of her dependence. Moreover, both Susan and Caspian hold positions as monarchs. By giving him her horn, Susan indicates that she regards Caspian as her equal. However, her being rescued by Caspian proves otherwise. Despite her supposed independence and equality, the male Caspian must save her life. A while earlier, the film gives its viewers the impression that Susan could be the one to rescue Caspian at his time of need; this scene proves otherwise.

Bordwell and Thompson [4] assert that "in some films, angles, and distance imply meanings." According to them, the low camera angle automatically presents a powerful character, and a high angle denotes a defeated character (p. 191). When Caspian saves Susan, the scene is shot to make Susan look weak. She is positioned below Caspian who is positioned higher, on a horse, offering his hand to her. Caspian is framed from a low angle, which emphasizes his ascendance; Susan is shot lying on the ground, from a high camera angle, which underscores her defeat. The very framing indicates the power Caspian holds over Susan at that moment. In another scene of the film, Susan almost falls to her death from a height but is rescued by Trumpkin, one of the male dwarfs standing beside her (01:57:52 01:58:00[1]). Susan saves two male figures in earlier scenes: first, along with Peter and Edmund, she saves Trumpkin from captivity (24:22-24: 27[1]); second, she shoots a Telmarine soldier who wants to kill Edmund (01:07:1401:07:20[1]). The film neutralizes those heroic acts by now showing her being saved by two male figures. Once more, Susan becomes a weak female who requires male help to sustain her life. Despite the active roles given to her as an asset in battle, a practical strategist, a skilled archer, and a powerful individual who saves other people on several occasions, her empowerment loses much of its value when she has to be rescued. When all is said and done, men must still ultimately rescue women.

Despite the film's evident and substantial transformation of Susan's character from the novel, she is still ultimately portrayed as a woman who requires saving by men. The film, therefore, portrays authority and power as qualities that finally vest in male characters. Peter consistently reaffirms actions that reflect his authority and power. The social structure that positions males ahead of females is embedded in Peter's actions and in his words that relegate others to the background. Peter dominates Susan as well as all others around him simply by virtue of his position as the High King. Caspian and Trumpkin also contribute to the perpetuation of the idea that men save women.

\section{Conclusions}

In conclusion, Susan's representation in the 1951 novel is conventional and conforms to the prevailing gender stereotypes of women being weaker than men. She is not agentic and is never shown as a powerful female figure.

In comparison, the novel's 2008 film adaptation imagines Susan as much more independent, capable of using her weapon in combat and is also more active in exhibiting her agency. None of these characteristics are accorded to Susan in the novel. It is thus evident that the film tries to represent Susan as a more empowered character. However, Susan's mastery in archery is never showcased and its potential remains unfulfilled because of her femininity restrains her from targeting a living being, a living bear in this instance. Her feminine prohibitions allow another person, a male, to take over the action. Her agency and voice are also limited in several instances when her voice is suppressed by male figures. This subjugation of the female voice is particularly true in the battle-related segments in which authority is always shown to rest in male figures. Her independence is also limited because she still needs male characters to rescue her from her predicaments.

While the film attempts and claims to break away from a stereotypical gender representation of Susan, the gender bias remains. The film's portrayal of Susan aptly represents the condition of women in contemporary times: despite their nominal gender equality, they must still face patriarchal 
restrictions because of the gendered imagining of their agency, whether physical, emotional, or mental.

\section{Acknowledgment}

I am grateful to my lecturer, Dr. Dhita Hapsarani, S.S., M.Hum., for her support, feedback, critique, and guidance throughout the process of conceiving and writing this paper. I also thank my colleague, Anindita Larasati, for her critique, feedback, and proof-reading during the writing of this paper. I especially acknowledge my family and partner, who have steadfastly supported me from the inception to the completion of my journey.

\section{References}

[1] Johnson, M. \& Adamson, A. (2008). The chronicles of Narnia: Prince Caspian.[Motion picture]. United Kingdom: Walden Media \& Walt Disney Pictures.

[2] Trites, R. S. (1997). Waking sleeping beauty: Feminist voices in children's novels. Iowa City: University of Iowa Press.

[3] Hall, S. (1997). Representation. Representation: Cultural representations and signifying practices. London: Sage in association with the Open University.

[4] Bordwell, D. \& Thompson, K. (2013). Film art: An introduction 10th edition. New York, NY: McGraw-Hill. E-book.

[5] McDonough, M. S. (2017). From damsel in distress to active agent: Female agency in children's and young adult fiction. Electronic $\begin{array}{llll}\text { Theses and Dissertations. } & \end{array}$ https://doi.org/10.18297/etd/2728।

[6] Duine, V. (2015). Restrictions in masculinity: Gender performance in children's literature. Retrieved from https://dspace.library.uu.nl/handle/1874/338658

[7] Pullman, P, A. A. (1998). The dark side of Narnia. The Guardian Retrieved from http://judithwolfe.wp.standrews.ac.uk/files/2017/08/Philip-Pullman-The-Dark-Side-ofNarnia-The-Guardian.docx

[8] Schilling, E. G. (2017). What about Susan? Gender in Narnia. Student Publications. 572. Retrieved from https://cupola.gettysburg.edu/cgi/viewcontent.cgi?article=1649\&conte $\mathrm{xt}=$ student_scholarship

[9] O'Donnell, K. C. (2013). The lion, the witch, and the discourse: A critical examination of gender and race in The Chronicles of Narnia series. $\quad$ Retrieved from https://digital.library.txstate.edu/bitstream/handle/10877/4704/ODON NELL-THESIS-2013.pdf?sequence $=1$

[10] Seabrook, A. \& Adamson, A. (2008). Narnia Adapted for the Screen in 'Prince Caspian' [Interview transcript]. Retrieved from National Public Radio website: https://www.npr.org/templates/story/story.php?storyId=90359670

[11] Nickel, E. H. (2015). Whiner or warrior? Susan Pevensie's role in the novel and film versions of The Chronicles of Narnia. In Khoddam, S., In Hall, M. R., \& In Fisher, J. (1st Ed.), C.S. Lewis and the Inklings: Reflections on faith, imagination and modern technology (p. 255274). Cambridge Scholars Publishing.

[12] Weitzman, L. J., Eifler, D., Hokada, E., \& Ross, C. (1972). Sex-role socialization in picture books for preschool children. American Journal of Sociology, 77(6), 1125-1150.
[13] Ward, Paul. (2004). Britishness since 1870. New York, NY: Routledge. E-book.

[14] Lewis, C. S. (2015). The chronicles of Narnia: Prince Caspian. London: HarperCollins Children's Books. Print.

[15] Vermeij, M. (2014). Lost girls: Gender stereotyping in the children's literary fantasy of C.S. Lewis, J.R.R. Tolkien and Elizabeth Goudge. Retrieved https://openaccess.leidenuniv.nl/bitstream/handle/1887/29580/Thesis $\% 20$ Final $\% 20$ Version $\% 20 \% 282 \% 29$.pdf?sequence $=1$

[16] Townsend, J. R. (2003). Written for children: an outline of Englishlanguage children's literature ( $6^{\text {th }}$ ed). Scarecrow Press, Inc.

[17] Cruea, S. M. (2005). Changing ideals of womanhood during the nineteenth-century woman movement. General Studies Writing Faculty Publications. Paper 1.

[18] Tsatsa, F. (2013). Gender roles in Harry Potter: Stereotypical or unconventional?. Retrieved from https://gupea.ub.gu.se/bitstream/2077/33244/1/gupea_2077_33244_1. pdf

[19] Dutt, R. (2014). Behind the curtain: Women's representations in contemporary Hollywood. MEDIA@LSE MSc Dissertation Series. Retrieved from http://www.lse.ac.uk/media@1se/research/mediaWorkingPapers/MSc DissertationSeries/2013/msc/112-Dutt.pdf

[20] Clark, C. \& Henderson, J. J. (2018). Oh, my god! I CAN FLY!': Female agency in Marvel's Runaways. Journal of Graphic Novels and Comics. DOI: 10.1080/21504857.2018.1437053

[21] Barker, C. (2003). Agency and the politics of identity. In cultural studies: theory and practice (pp. 233-239). London, UK: SAGE Publications.

[22] Adams, H. (2016). The representation of gender in British and German children's literature after 1950: A comparative study of six selected children's books. DOI: 10.13140/RG.2.2.24782.15683

[23] Jones, P. (2018). Diana in the world of men: A character network approach to analysing gendered vocal representation in Wonder Woman. Feminist Media https://doi.org/10.1080/14680777.2018.1510846

[24] Kempton, E. R. (2016). Hope for Susan: Moral imagination in The Chronicles of Narnia. All Theses and Dissertations. 5989. Retrieved from https://scholarsarchive.byu.edu/etd/5989

[25] Lee, A. (2017). 'Beauty and the Beast': 9 differences between the live-action and animated movies - and why they matter. The Hollywood Reporter. Retrieved from https://www.hollywoodreporter.com/lists/beauty-beast-differencesbetween-animated-live-action-movies-why-they-matter986622/item/beauty-beast-movie-differences-belle-986634

[26] Macleod, M. (2017). Be the one that rescues you: contexts for the construction of agency in Kenneth Branagh's "Cinderella". DOI: $10.12957 /$ soletras.2016.27186

[27] Patchin, A. K. (2011). Once a queen in Narnia: Susan and the divine in C.S. Lewis's Chronicles of Narnia. Retrieved from https://scholarworks.boisestate.edu/cgi/viewcontent.cgi? article $=1225$ \&context $=\mathrm{td}$ 